RADOVI

Zavoda za znanstveni rad HAZU Varaždin

ANDREJA BRAJŠA-ŽGANEC Institut društvenih znanosti Ivo Pilar, Zagreb Andreja.Brajsa.Zganec@pilar.hr DOI: http://doi.org/10.21857/moxpjho7vm

UDK 304(497.523Varaždin):061.1EU Izvorni znanstveni članak Original Scientific Paper

Primljeno: 07. 02. 2017. Prihaćeno: 15. 11. 2017.

GORAN KOZINA

Sveučilište Sjever, Sveučilišni centar Varaždin

goran.kozina@unin.hr

Postoji niz čimbenika koji pridonose kvaliteti života pojedinca. Cilj istraživanja bio je ispitati kvalitetu življenja građana grada Varaždina odnosno procjena općeg životnog zadovoljstva kao $i$ pojedinih domena životnog zadovoljstva $i$ sreće građana grada Varaždina te napraviti usporedbu s procjenama kvalitete života građana Hrvatske, susjednih zemalja i općenito građana Europske unije. Rezultati provedenog istraživanja pokazali su da stanovnici grada Varaždina procjenjuju da su sretni i zadovoljni svojim životom u cijelosti. Za zadovoljstvo životom građana grada Varaždina najznačajniji su zadovoljstvo životnim standardom $i$ zadovoljstvo pripadnosti okolini u kojoj žive. Građani Varaždina procjenjuju svoje životno zadovoljstvo i sreću nešto više od građana Hrvatske i građana EU-a.

\title{
UVOD
}

Kvalitetu života nekog pojedinca čine svi oni čimbenici koji imaju utjecaj na stupanj njegova blagostanja odnosno na životne uvjete tog pojedinca i društva. Dva su znanstvena pristupa mjerenju kvalitete života, a to su mjerenje objektivnih okolnosti života pojedinca odnosno socijalnih indikatora ili mjerenje subjektivnog iskustva pojedinca o njegovom životu (Diener i Suh, 1997). Postoji niz čimbenika koji pridonose kvaliteti života pojedinca - od okolinskih do čimbenika povezanih sa samim pojedincem, kao što je obrazovanje, mogućnost zapošljavanja, socijalni status, zdravlje itd. Kada govorimo o subjektivnim procjenama kvalitete života, govorimo o dobrobiti. Dobrobit se definira kao kognitivna i emocionalna evaluacija života (Diener, Oishi, 
i Lucas 2003). Subjektivnu procjenu kvalitete života predstavlja procjena životnog zadovoljstva i sreće, koja može biti pod utjecajem mnogih individualnih i okolinskih čimbenika (Diener, 2000), a široko gledano odnosi se na evaluaciju pojedinca - kako njegovog života tako i događaja, okolnosti i reakcija na njih (Kim-Prieto et al., 2005; Diener, 2006). Istraživači se bave dobrobiti kao globalnom procjenom ili procjenom specifičnih domena zadovoljstva životom te procjenom pozitivnih i negativnih emocionalnih odgovora (Diener, Suh, Lucas, \& Smith, 1999). Prema Dieneru (1984), subjektivna dobrobit ima tri osnovne karakteristike: subjektivna je i ovisi o iskustvu; uključuje ne samo odsutnost negativnih doživljaja već uključuje i pozitivne doživljaje te se odnosi na subjektivnu procjenu svih aspekata života. Zadovoljstvo životom odnosi se na kognitivnu komponentu dobrobiti, a definira se kao kognitivna evaluacija života u cjelini, događaja koji su se dogodili pojedincu, i to u okolnostima u kojima živi (Diener, 2006). Prilikom procjene zadovoljstva životom, pojedinac prvo istražuje različite aspekte svog života i uspoređuje ih s onim čemu teži i što mu je ideal, a nakon toga čini procjenu zadovoljstva životom u cjelini. Tijekom tog procesa pojedinci koriste svoje osobne kriterije i skup vrijednosti koji čine razlike u cjelokupnom životnom zadovoljstvu (Pavot i Diener, 2004). Sreća kao emocionalna komponenta dobrobiti odnosi se na emocionalne odgovore, odnosno češće i u većini vremena doživljavanje ugodnih emocija u odnosu na neugodne emocije (Diener, 2006; Veenhoven, 2010).

Determinante dobrobiti vezane su uz karakteristike pojedinca i društva u kojem on živi. Na razini individualnih karakteristika više procjene dobrobiti povezane su s boljim zdravljem i funkcionalnim sposobnostima, boljim odnosima s članovima obitelji i prijateljima, boljim uvjetima života, mogućnošću zapošljavanja, višim mjesečnim prihodima po članu kućanstva, bavljenjem slobodnim aktivnostima i sl. (Diener, Suh, Lucas, \& Smith, 1999; Stoll, Michelson i Seaford, 2012; Kaliterna Lipovčan, Brkljačić, Šakić, 2007; Kaliterna Lipovčan; Burušić, 2014; Brajša-Žganec, Merkaš, Šverko, 2011; Eurofound, 2014). Istodobno promjene u objektivnim okolnostima imaju malen utjecaj na procjenu dobrobiti (Cummins, 2012). Razvojem nekog društva dobrobit je otporna na promjene i više je pod utjecajem individualnih karakteristika pojedinca nego okolinskih uvjeta (Cummins, 2012). Tako je u zemljama u tranziciji, koje iz socijalističkog uređenja prelaze na ono kapitalističko, zabilježen veći porast razlika u procjeni dobrobiti između bogatih i siromašnih pojedinaca. Mogući razlozi su zabrinutost pojedinaca koji pripadaju dijelu populacije $\mathrm{u}$ kojoj je $\mathrm{u}$ tom tranzicijskom periodu došlo do porasta nezaposlenosti i povećanja materijalne nejednakosti (Easterlin, 2012). Hrvatska je zemlja u tranziciji koja je 2008. godine ušla u razdoblje recesije, a nepovoljni gospodarski trendovi prisutni su od samog početka krize. Tek je 2011. godine stopa rasta BDP-a bila nula, što je ukazivalo na mogući kraj gospodarske krize (Kaliterna Lipovčan, Babarović, Brajša-Žganec, Bejaković, Japec, 2015). Hrvatska je u odnosu na ostale članice EU-a prema procjenama životnog zadovoljstva stanovništva 
na samom začelju, dok su države u kojima su stanovnici najzadovoljniji životom skandinavske zemlje (Eurobarometar, 2015). U tom širem kontekstu grad Varaždin svojim geopolitičkim položajem kao razvijeno kulturno, povijesno i gospodarsko središte sjeverozapadne Hrvatske ima među prvim gradovima poziciju za napredak, koja bi mogla nagovijestiti pozitivne trendove razvoja.

Kako bi se dobio uvid u kvalitetu života građana grada Varaždina, cilj ovog istraživanja jest ispitati kvalitetu življenja građana grada Varaždina te napraviti usporedbu s procjenama kvalitete života građana Hrvatske, susjednih zemalja i općenito građana Europske unije. Konkretno, zanima nas procjena općeg životnog zadovoljstva kao i pojedinih domena životnog zadovoljstva i sreće građana grada Varaždina te usporedba tih rezultata s procjenama građana Hrvatske, susjednih zemalja i građana Europske unije. Do sada se kvaliteta života hrvatskih građana uspoređivala po regijama (UNDP, 2006) te prema drugim zemljama EU-a i šire (npr. Eurofound, 2014; Eurobarometar, 2015), a u ovom radu posebno želimo usporediti procjene kvalitete života građana Varaždina sa stanovnicima Hrvatske kao i s građanima susjednih zemalja.

\section{METODOLOGIJA ISTRAŽIVANJA:}

Istraživanje je provedeno 2011. godine u sklopu znanstveno-istraživačkog projekta Razvojne perspektive visokoškolskog obrazovanja u gradu Varaždinu, koji je provodio Institut društvenih znanosti Ivo Pilar - Područni centar Varaždin u suradnji sa Sveučilištem Sjever Varaždin, tada Veleučilištem u Varaždinu. U okviru projekta ispitivali su se stavovi građana, stanovnika Varaždina, o razvojnim pitanjima, perspektivi i kvaliteti življenja u Varaždinu, što je trebalo predstavljati polaznu osnovu za javni dijalog o budućem razvoju i razvojnim prioritetima u Varaždinu. Projekt je imao cilj analizirati kvalitetu života i razvojnih prednosti i nedostataka kako ih doživljavaju stanovnici Varaždina te je bio zamišljen u nekoliko povezanih faza, koje se mogu interpretirati i kao zasebne istraživačke cjeline.

\section{Način prikupljanja podataka i provedba istraživanja na terenu}

Prikupljanje podataka za potrebe znanstveno-istraživačkog projekta provedeno je metodom anketnog istraživanja, pri čemu je anketiranje obavljeno na adresi stanovanja, tehnikom lice u lice. Anketa je bila anonimna, a anketni upitnik je ukupno imao 53 pitanja, od kojih je najveći dio bio zatvorenog tipa. U pripremi istraživanja instruiralo se anketare o načinu na koji se vrši postupak odabira ispitanika. Precizno je objašnjen cijeli postupak odabira ispitanika, od toga da se u kućanstvu odabire član koji je posljednji imao rođendan (u slučaju preklapanja datuma anketira se mlađa osoba), pa do načina odabira zamjenskog kućanstva u slučaju da u odabranom 
kućanstvu nije bilo moguće obaviti anketiranje (zbog odbijanja, nepostojeće adrese i sl.). Ispitanici su bili obaviješteni o svrsi istraživanja te im je zagarantirana anonimnost, a svi podaci prikupljeni od sudionika prikazani su skupno. Uz to svim ispitanicima je naglašena dobrovoljnost sudjelovanja $u$ istraživanju kao i povjerljivost podataka. Svaki ispitanik je u potpunosti slobodno i samostalno odlučio o sudjelovanju u ovom istraživanju, te je u bilo koje vrijeme, bez navođenja razloga, imao pravo odustati od daljnjeg odgovaranja na pitanja u anketi.

\section{Uzorak}

Istraživanje je provedeno na reprezentativnom, stratificiranom uzorku punoljetnog stanovništva Grada Varaždina, sa slučajnim izborom jedinica unutar svakog stratuma. Uzorkom je ukupno obuhvaćeno 500 ispitanika. Stratificirani uzorak korišten je kako bi se osigurala adekvatna zastupljenost dviju važnih naseljskih komponenta - središnjeg gradskog naselja i prigradskih ruralnih i rurbanih naselja. Stratumi stratificiranog uzorka organizirani su tako da je jedan obuhvatio 400 ispitanika iz središnjeg gradskog naselja (Varaždin), a drugi je obuhvatio 100 ispitanika s područja devet prigradskih naselja (Črnec Biškupećki, Donji Kućan, Gojanec, Gornji Kućan, Hrašćica, Jalkovec, Kućan Marof, Poljana Biškupećka, i Zbelava). Naknadno je ponderiranjem usklađena proporcionalna zastupljenost naznačenih stratuma uzorka sukladno njihovoj zastupljenosti u populaciji, a istim postupkom korigirano je i odstupanje spolne te dobne strukture uzorka od populacijskih vrijednosti.

Osnovna obilježja ispitanika prema spolu, dobi i obrazovnoj strukturi prikazani su u Tablici 1.

Tablica 1: Osnovna obilježja ispitanika prema spolu, dobi i obrazovnoj strukturi

\begin{tabular}{|l|l|l|}
\hline & & \\
\hline spol & muški & $46,3 \%$ \\
\hline dob & ženski & $53,7 \%$ \\
\hline & do 34 & $28,9 \%$ \\
\hline & $35-64$ & $52,3 \%$ \\
\hline stupanj obrazovanja & više od 65 & $18,8 \%$ \\
\hline & osnovna škola & $10,8 \%$ \\
\hline & srednja stručna sprema & $59,4 \%$ \\
\hline & viša i visoka stručna sprema & $29,8 \%$ \\
\hline
\end{tabular}




\section{Instrumenti}

Za potrebe ovog rada korištene su subjektivne procjene kvalitete življenja građana Varaždina ispitane skalama samoprocjena o kvaliteti života, životnom zadovoljstvu i sreći te pojedinim domenama životnog zadovoljstva. Za procjene korištene su Likertove skale većinom u rasponu od 0 do 10 ( 0 znači izrazito nezadovoljni, 5 ni zadovoljni ni nezadovoljni a 10 izrazito zadovoljni). Anketa se sastojala od pitanja napravljenih za potrebe samog istraživanja, od prerađenog Međunarodnog indeksa dobrobiti (International Well-Being Index) autora Cummins i suradnika (2003) te pitanja o procjeni životnog zadovoljstva i sreće. Mjera zadovoljstva životom preuzeta je iz European Social Survey Well-being module (Huppert et al. 2009), koja je originalno adaptirana iz Dienerove i suradnika Skale zadovoljstva životom (SWLS; Diener et al. 1985), a sastoji se od jedne čestice koja mjeri koliko je ispitanik zadovoljan svojim životom u cijelosti te mjere sreće (Fordayce, 1998), koja se također sastoji od jedne čestice.

Podaci za usporedbu s procjenama životnog zadovoljstva i sreće stanovnika Hrvatske i pojedinih susjednih zemalja EU-a uzeti su iz Europskog istraživanja o kvaliteti života (EQLS) EUROFOUND-a (2014). Istraživanje je također provedeno u jesen 2011. godine na stratificirano slučajnim uzorcima, a uključivalo je ispitanike iz 27 država članica EU-a i Hrvatske (broj ispitanika kretao se od 1000 do 3000, od zemlje do zemlje). Kako bi se napravila usporedba procjena životnog zadovoljstva u cjelini i prema pojedinim domenama, te sreće, s procjenom životnog zadovoljstva i sreće građana EU-a, čije procjene su ispitane na Likertovoj skali od 1 do 10 stupnjeva, napravljena je transformacija prikupljenih rezultata procjena građana Varaždina na skalu od također 10 stupnjeva (od 1 do 10) (prema Batz, Parrigon, Tay 2015). O ograničenju usporedbe podataka dobivenih na različitim skalama više $u$ radovima de Jonge, Veenhoven, Arends (2014) i Kristoffersen (2017).

\section{Obrada podataka}

Provedena je statistička obrada podataka deskriptivne statistike te regresijska analiza. Ovisno o vrsti varijable, za prikaz distribucija korišteni su postoci ili frekvencije, a kod dijela varijabli prikazana je i aritmetička sredina kao mjera centralne tendencije. Sve statističke analize obavljene su u programu SPSS 19. 


\section{Rezultati i rasprava}

\section{Kvaliteta života građana grada Varaždina}

Ocjenjujući kvalitetu življenja koju grad nudi svojim stanovnicima, na ljestvici od 1 do 5 ispitanici su dali ocjenu 3,5, tj. ostali su na „donjem pragu“ ocjene vrlo dobar. Usporedba s kvalitetom življenja u drugim hrvatskim gradovima pokazala je da većina smatra kako je kvaliteta življenja u Varaždinu bolja od hrvatskog prosjeka (59,1\%) (Slika 1). Gotovo 85\% stanovnika kvalitetu života u gradu procjenjuju dobrom ili vrlo dobrom.

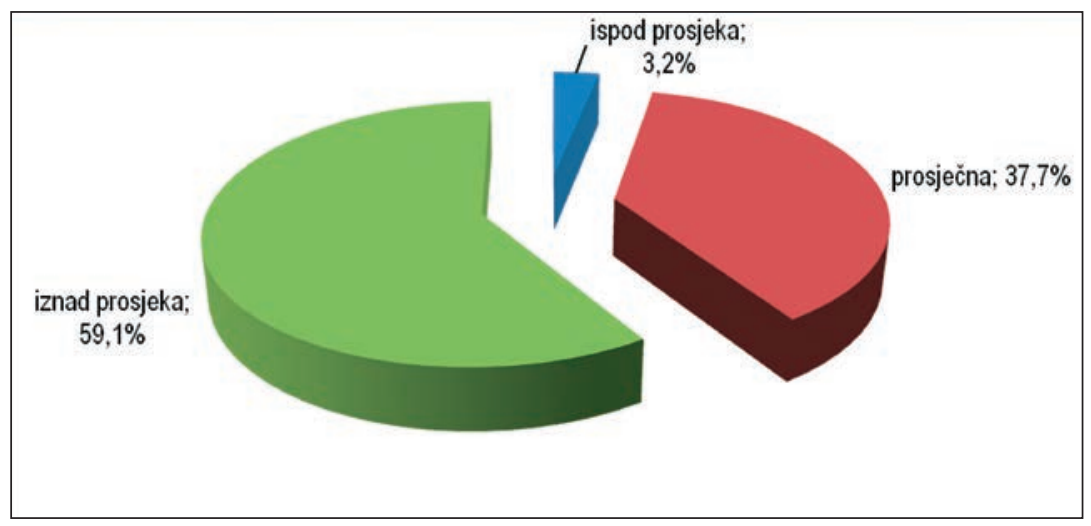

Slika 1. Ocjene opće kvalitete života građana u gradu Varaždinu u usporedbi s drugim hrvatskim gradovima

Kako bi kvaliteta življenja bila još bolja, ispitanici smatraju da bi trebalo unaprijediti u prvom redu mogućnost zapošljavanja (88,1\%), zatim kvalitetu zdravstvenih usluga $(35,2 \%)$, a na visokom trećem mjestu prioriteta nalazi se i unaprjeđenje visokog i višeg obrazovanja (29,1\%) (Slika 2). Ovi prioriteti kompatibilni su is prilikama u državi, u kojima se od početka recesije ističe problem manjka radnih mjesta te relativno nezadovoljstvo zdravstvenim institucijama. Građani Varaždina ponajprije žele unaprijediti mogućnost zapošljavanja, iako je Varaždin na samom vrhu Hrvatske s obzirom na nisku stopu nezaposlenosti. Ove nalaze možemo objasniti većim brojem slabije plaćenih poslova koji se nude građanima Varaždina, jer su prosječne visine plaća u Varaždinu u odnosu na ostale dijelove Hrvatske niže (DZS, 2017). Zanimljivo je da građani percipiraju razvoj visokoškolskog obrazovanja kao važniji preduvjet za poboljšanje kvalitete življenja nego npr. komunalnu infrastrukturu, javni prijevoz ili opću sigurnost. 


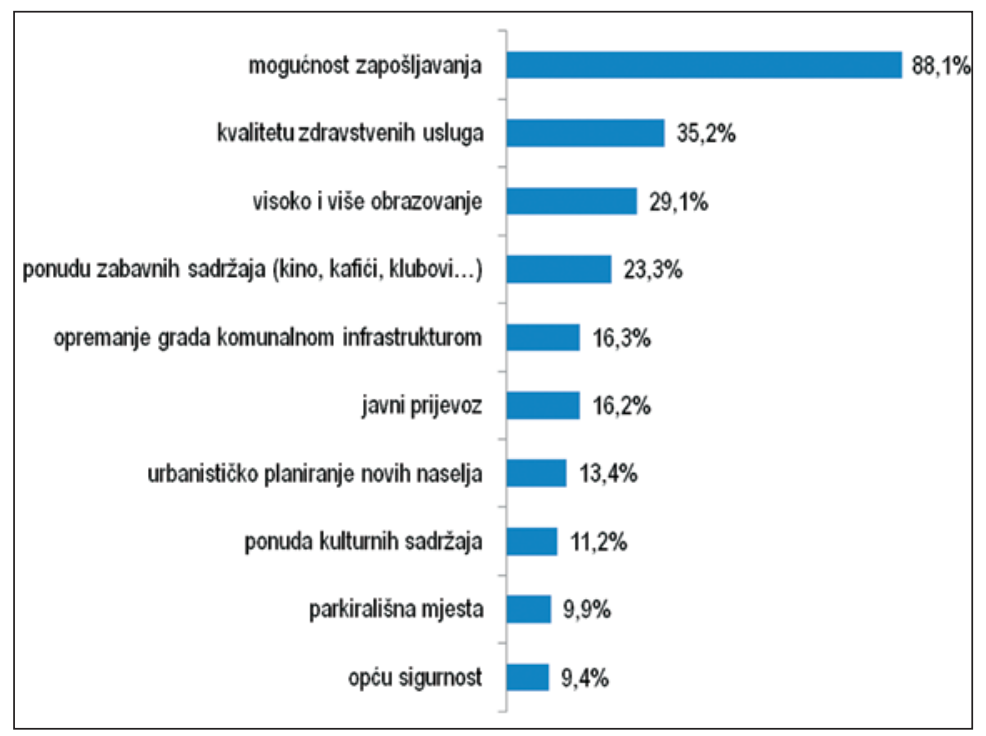

Slika 2. Procjene građana grada Varaždina o tome što bi trebalo prioritetno unaprijediti kako bi se podigla razina kvalitete života u gradu (bilo je moguće odabrati do tri odgovora)

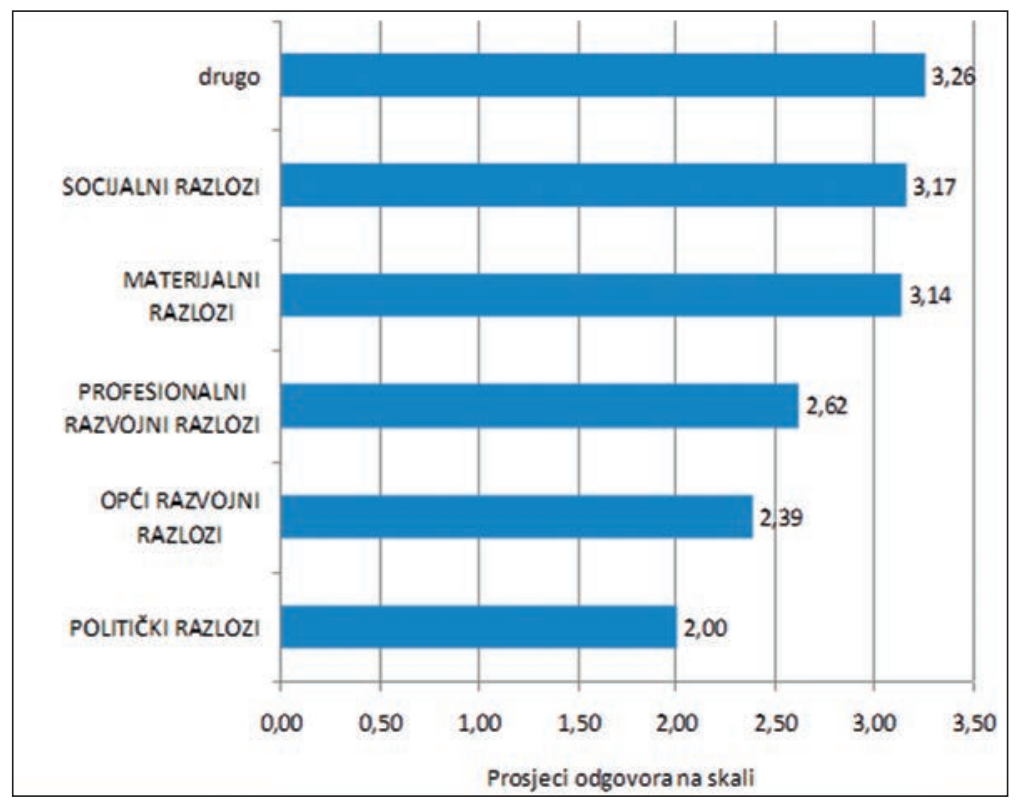

Slika 3. Procjene građana koliko su im osobno važni (ili bi mogli biti važni) pojedini razlozi odlaska iz Varaždina (teoretski raspon odgovora je od 1=potpuno nevažni, do 5=izrazito važni) 
Nadalje, građani Varaždina procjenjuju da bi im među važnijim razlozima za odlazak iz grada bili tzv. socijalni razlozi (zbog obitelji, partnera, prijatelja M=3,17), a manje su važni politički, profesionalni ili razvojni razlozi (Slika 3).

Procjenjujući životno zadovoljstvo, građani grada Varaždina vrlo su se pozitivno izjasnili. Na ljestvici od 0, koja označava izrazito nezadovoljstvo, do 10, koje označava izrazito zadovoljstvo, prosječna procjena građana Varaždina jest $M=7,25$. Ako tome dodamo i procjenu na istoj skali koliko su sretni građani Varaždina, a koja iznosi M=7,42, može se zaključiti kako općenito stanovnici grada Varaždina procjenjuju da su sretni i zadovoljni svojim životom u cijelosti. Procjene o zadovoljstvu pojedinim domenama u svom životu odnosno uvjetima življenja u gradu Varaždinu općenito, govore da su građani najzadovoljniji odnosima s bližnjima, pripadnošću okolini u kojoj žive, kvalitetom stanovanja, zatim duhovnošću, osjećajem vlastite sigurnosti i sigurnosti u gradu. Najbliže kategoriji procjene 5, što označava neutralnu procjenu, građani procjenjuju vlasti i upravu grada, biznis i poduzetništvo u gradu, ekonomsku situaciju u gradu i socijalne uvjete u gradu (Slika 4). Može se zaključiti da građani svoje pozitivne procjene zadovoljstva životom uglavnom temelje na općim prilikama u gradu te na vlastitom životnom standardu, međuljudskim odnosima i osjećaju sigurnosti.

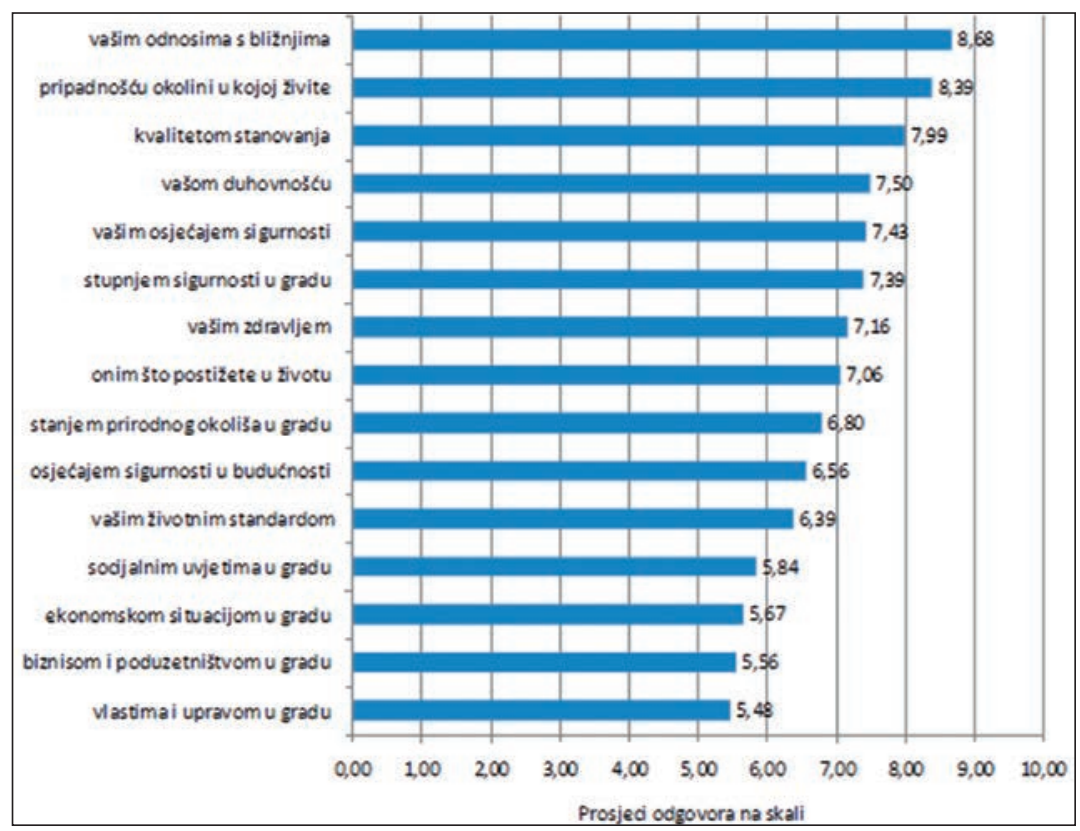

Slika 4. Procjene građana koliko su zadovoljni pojedinostima u svom životu odnosno uvjetima života u gradu Varaždinu općenito. (prikazane su prosječne vrijednosti procjena; teoretski raspon odgovora je od 0 - izrazito nezadovoljan do 10 - izrazito zadovoljan) 
Kako bi se ispitao doprinos svakog pojedinog čimbenika na zadovoljstvo životom, provedena je regresijska analiza. Prediktorske varijable uključivale su sociodemografske varijable te zadovoljstvo pojedinim osobnim domenama života, i to životnim standardom, zdravljem, onim što se postiže u životu, odnosima s bližnjima, osjećajem sigurnosti, pripadnošću okolini u kojoj se živi, kvalitetom stanovanja, osjećajem sigurnosti u budućnosti i duhovnošću. Regresijska analiza pokazala je da su, uz kontrolu sociodemografskih varijabli (spol, dob, prihodi po članu kućanstva, obrazovanje), najznačajniji prediktori zadovoljstva životom $(R=0.75 ; 55 \%)$ zadovoljstvo životnim standardom $(\Omega=0.39 ; \mathrm{p}=0.00)$ i zadovoljstvo pripadnosti okolini u kojoj žive $(ß=0.15 ; \mathrm{p}=0.00)$.

Bolji životni standard te mogućnost zapošljavanja, prema dobivenim rezultatima, povezani su s procjenama životnog zadovoljstva i govore o važnosti gospodarske situacije za kvalitetu života građana. Zatim, kroz sudjelovanje u različitim aktivnostima ljudi razvijaju svoje socijalne odnose, osjećaju pozitivne emocije, usvajaju dodatne vještine i znanja i tako povećavaju svoju kvalitetu života. Postoji niz čimbenika koji mogu biti povezani s poboljšanjem kvalitete života odnosno životnog zadovoljstva i sreće pojedinaca. Uključivanje u različite vrste slobodnih aktivnosti - od aktivnog bavljenja različitim sportovima, izlasci i sl., do posjećivanja kulturnih događaja ili bavljenja obiteljskim i kućnim aktivnostima - doprinosi kvaliteti života pojedinca (Brajša-Žganec, Merkaš, Šverko, 2011). Tome možemo dodati da se uz gospodarstvo, u gradu Varaždinu kroz povijest posebno razvijaju kultura i sport, što je detaljno opisano u zborniku sa skupa 800 godina slobodnog kraljevskog grada Varaždina 1209. - 2009. (Šicel, Kaštela, 2009). Bavljenje različitim slobodnim aktivnostima - koje su u velikoj mjeri i danas, a i kroz povijest zastupljene u gradu Varaždinu - tako vjerojatno doprinosi kvaliteti života građana Varaždina. Budući da se u jednom prijašnjem istraživanju pokazalo kako su stanovnici mjesta u Hrvatskoj $\mathrm{s}$ višim procjenama kvalitete turističke ponude sretniji, zadovoljniji životom $\mathrm{u}$ cjelini, zadovoljniji materijalnim statusom, zdravljem, postignućem u životu, odnosima s obitelji i prijateljima itd. u odnosu na stanovnike iz mjesta koja su prosječna ili ispodprosječna po kvaliteti turističke ponude (Kaliterna Lipovčan; Brajša-Žganec, Borić, 2014), dodatno povećanje kvalitete života i sreće stanovnika Varaždina može se očekivati, uz ostale indikatore, i poboljšanjem kvalitete turističke ponude grada Varaždina. Naime, turistička ponuda je svake godine sve veća i opsežnija te nudi niz sadržaja kroz cijelu godinu. Naši rezultati govore kako ispitanici smatraju da bi kvaliteta življenja u gradu Varaždinu bila još bolja kad se unaprijedilo visoko i više obrazovanje. Ako znamo da je obrazovanje građana preduvjet za kritičko oblikovanje stavova o razvojnim pitanjima te da su stavovi obrazovanije populacije bliži konceptu socijalno održivog razvoja grada, kojim se smanjuje dominacija političkog sektora a afirmira dijalog različitih socijalnih sudionika (Mišetić, Krnić, 
Kozina, 2013), tada ulaganje u visoko obrazovanje i njegovo unaprjeđenje u gradu Varaždinu, koje se kontinuirano događa od provedbe ovog istraživanja 2011. godine do danas, kada grad ima svoje sveučilište, ide u pozitivnom smjeru poboljšavanja kvalitete života u gradu i socijalno održivog razvoja grada.

\section{Usporedba procjena kvalitete života građana Varaždina, Hrvatske i EU-a}

Usporedba procjena kvalitete života građana Varaždina, Hrvatske i EU-a prikazana je na slikama od 5 do 9. Općenito, Hrvatska u usporedbi s EU-om loše kotira kad je riječ o životnom zadovoljstvu, i na samom je začelju među članicama EU-a jer ima gotovo trećinu nezadovoljnih građana, dok je u prosjeku u EU-u nezadovoljnih 20 posto građana (Eurobarometar, 2015). Zemlje u kojima su stanovnici najzadovoljniji životom jesu Danska, Švedska, Nizozemska, a među najmanje zadovoljnima su stanovnici Španjolske, Portugala i Italije. Kada dobivene podatke procjena građana grada Varaždina usporedimo s prikupljenim podacima iz Europskog istraživanja o kvaliteti života (EQLS) EUROFOUND-a (2014.), koje je također provedeno u jesen 2011. godine, a uključivalo je 27 država članica EU-a i Hrvatsku, tada možemo jasno vidjeti da građani Varaždina procjenjuju svoje životno zadovoljstvo nešto višim od građana EU-a, a time i još više u odnosu na građane Hrvatske (Slika 5). Sreću građani Varaždina procjenjuju višom od građana Hrvatske i stanovnika EU-a (Slika 6), kao i kvalitetu stanovanja (Slika 7). Za razliku od ovih procjena zadovoljstvo svojim zdravljem građani Varaždina, Hrvatske i EU-a procjenjuju podjednako (Slika 8). Procjena životnog standarda unutar ove tri skupne, kao što se moglo i očekivati, najviša je u stanovnika EU-a, a najniža kod stanovnika Hrvatske, dok je vrlo interesantno da su procjene životnog standarda građana Varaždina bliže procjenama stanovnika EU-a (Slika 9). Kako bismo malo detaljnije opisali ove dobivene razlike, napravljena je usporedba procjena kvalitete života građana Varaždina i zemalja u okruženju. 
Andreja Brajša-Žganec, Goran Kozina: Kvaliteta življenja građana Grada Varaždina: usporedba s Europskom unijom Radovi Zavoda za znanstveni rad HAZU Varaždin, br. 28, 2017., str. 247 - 265

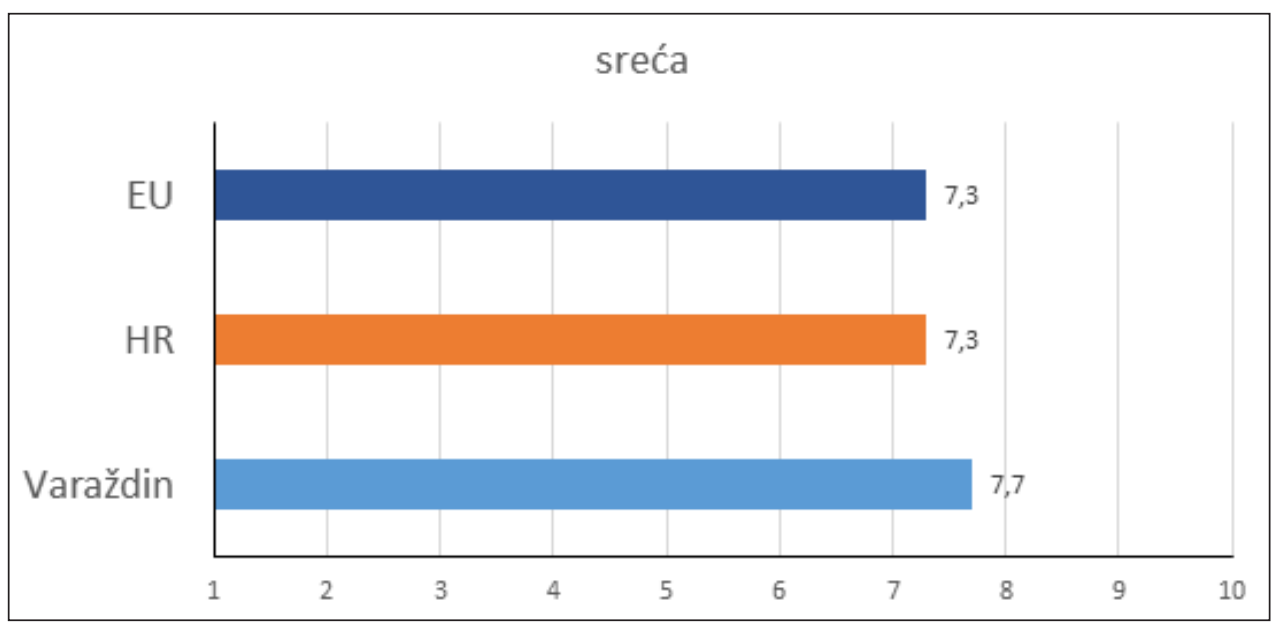

Slika 5. Usporedba procjene sreće stanovnika Varaždina, Hrvatske i EU-a

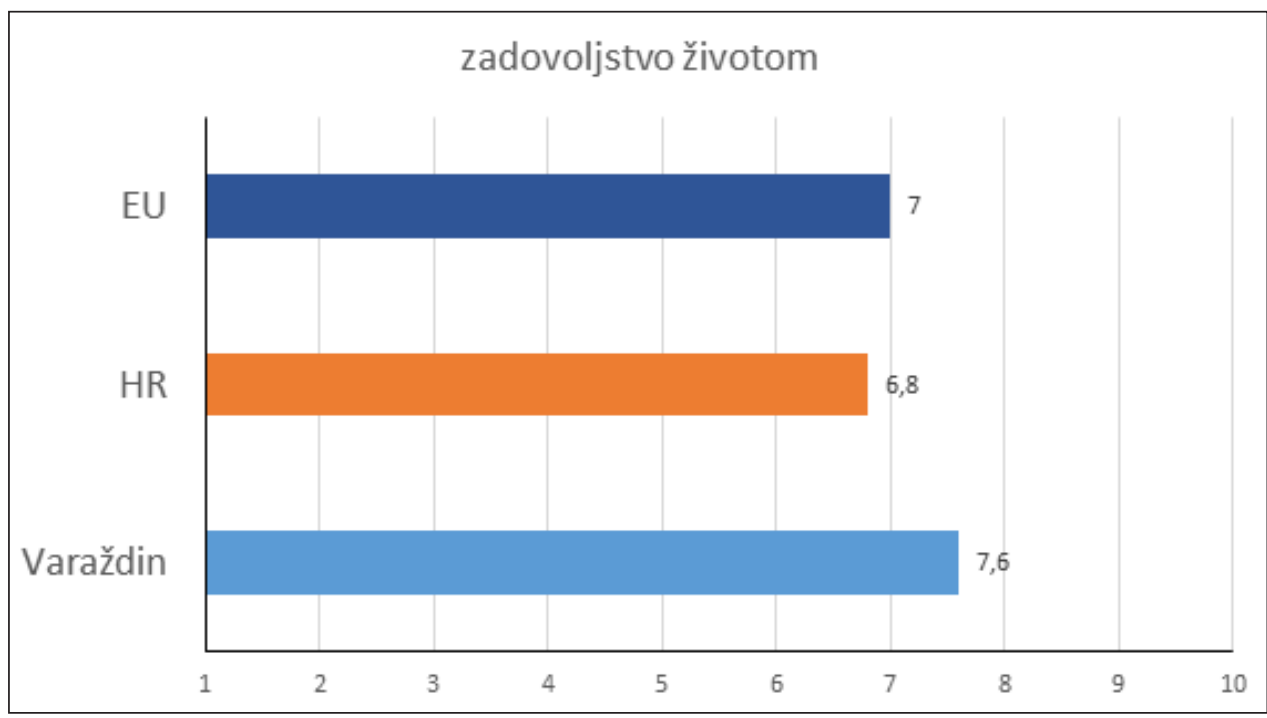

Slika 6. Usporedba procjene zadovoljstva životom stanovnika Varaždina, Hrvatske i EU-a 
Andreja Brajša-Žganec, Goran Kozina: Kvaliteta življenja građana Grada Varaždina: usporedba s Europskom unijom Radovi Zavoda za znanstveni rad HAZU Varaždin, br. 28, 2017., str. 247 - 265

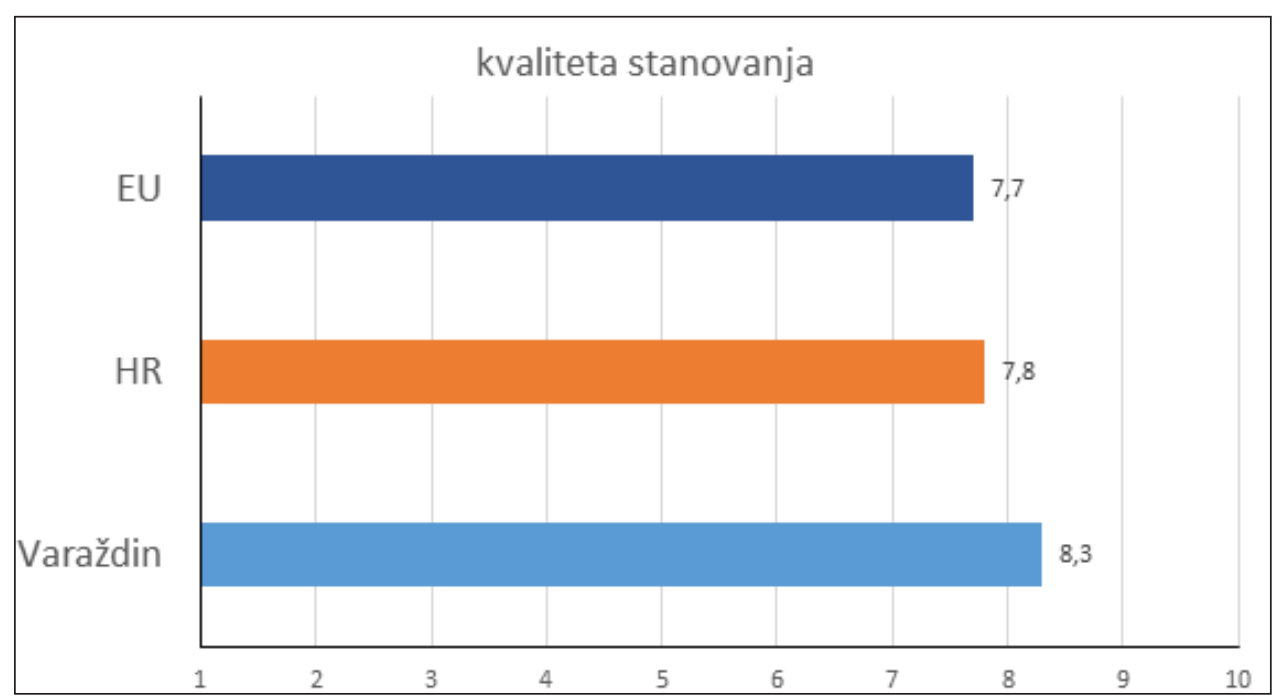

Slika 7. Usporedba procjene kvalitete stanovanja stanovnika Varaždina, Hrvatske i EU-a

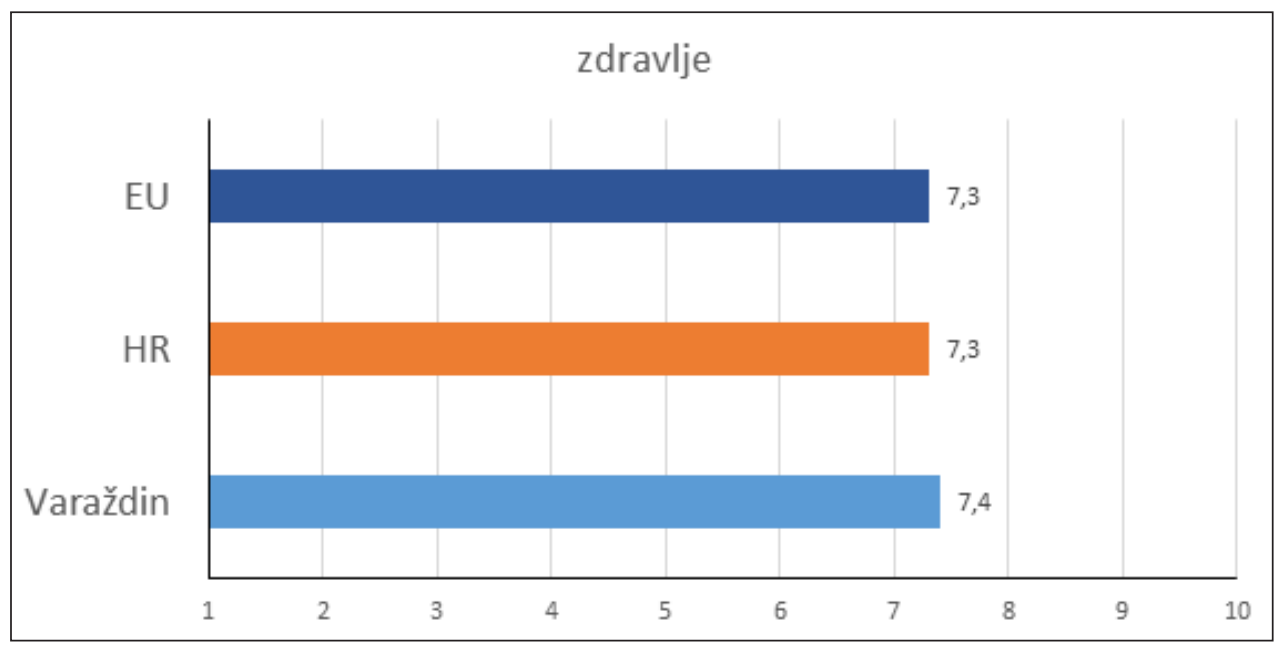

Slika 8. Usporedba procjene zdravlja stanovnika Varaždina, Hrvatske i EU-a 


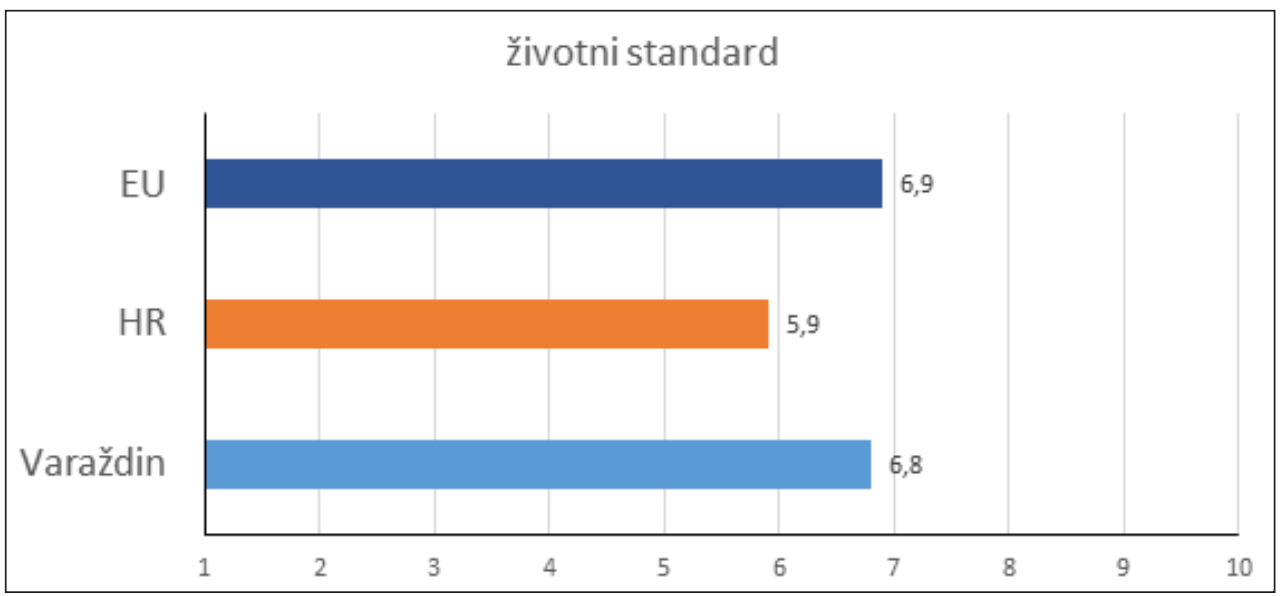

Slika 9. Usporedba procjene životnog standarda stanovnika Varaždina, Hrvatske i EU-a

\section{Usporedba procjena kvalitete života građana Varaždina i susjednih zemalja}

Usporedba procjena sreće i zadovoljstva životom stanovnika Varaždina, Slovenije, Mađarske, Austrije i Češke Republike prikazani su na slici 10. Najviše procjene životnog zadovoljstva i sreće od stanovnika Slovenije, Mađarske, Austrije i Češke Republike imaju stanovnici Austrije, dok stanovnici Mađarske svoju sreću i zadovoljstvo procjenjuju najniže. Ako usporedimo procjene stanovnika Varaždina s procjenama stanovnika iz ovih susjednih zemalja, možemo konstatirati da su procjene građana Varaždina najbliže odnosno gotovo identične procjenama stanovnika Austrije. Upravo ovi rezultati govore nam o doživljajima kvalitete života građana Varaždina i o okruženju u kojem žive. Grad Varaždin svojim geopolitičkim položajem kao razvijeno kulturno, povijesno i gospodarsko središte sjeverozapadne Hrvatske očito nudi svojim građanima zadovoljstvo u različitim domenama života, od stanovanja, prijatelja, sigurnosti i sl. Prema podacima Instituta za javne financije, kad je riječ o jedinicama lokalne samouprave poredanih po prihodima koje su ostvarile po glavi stanovnika u 2015. godini, Varaždin se nalazi na gornjoj polovini te zauzima 37. mjesto među 128 hrvatskih gradova (Ott, Bronić, Stanić, 2016). Uz niz nedostataka koji se navode kod ovih analiza, ipak ovakva slika o financijskom stanju jedinica lokalne samouprave jasno govori o dobrom položaju grada Varaždina u odnosu na ostale gradove u Hrvatskoj. U svjetlu istraživanja koja kažu da sretni ljudi svojim ponašanjem dovode do ponovnog uspjeha, pa tako i održavanja svoje sreće (Lyubomirsky, King, Diener, 2005), stanovnici grada Varaždina svojim visokim procjenama sreće imaju niz pretpostavka da je i dalje održavaju. 


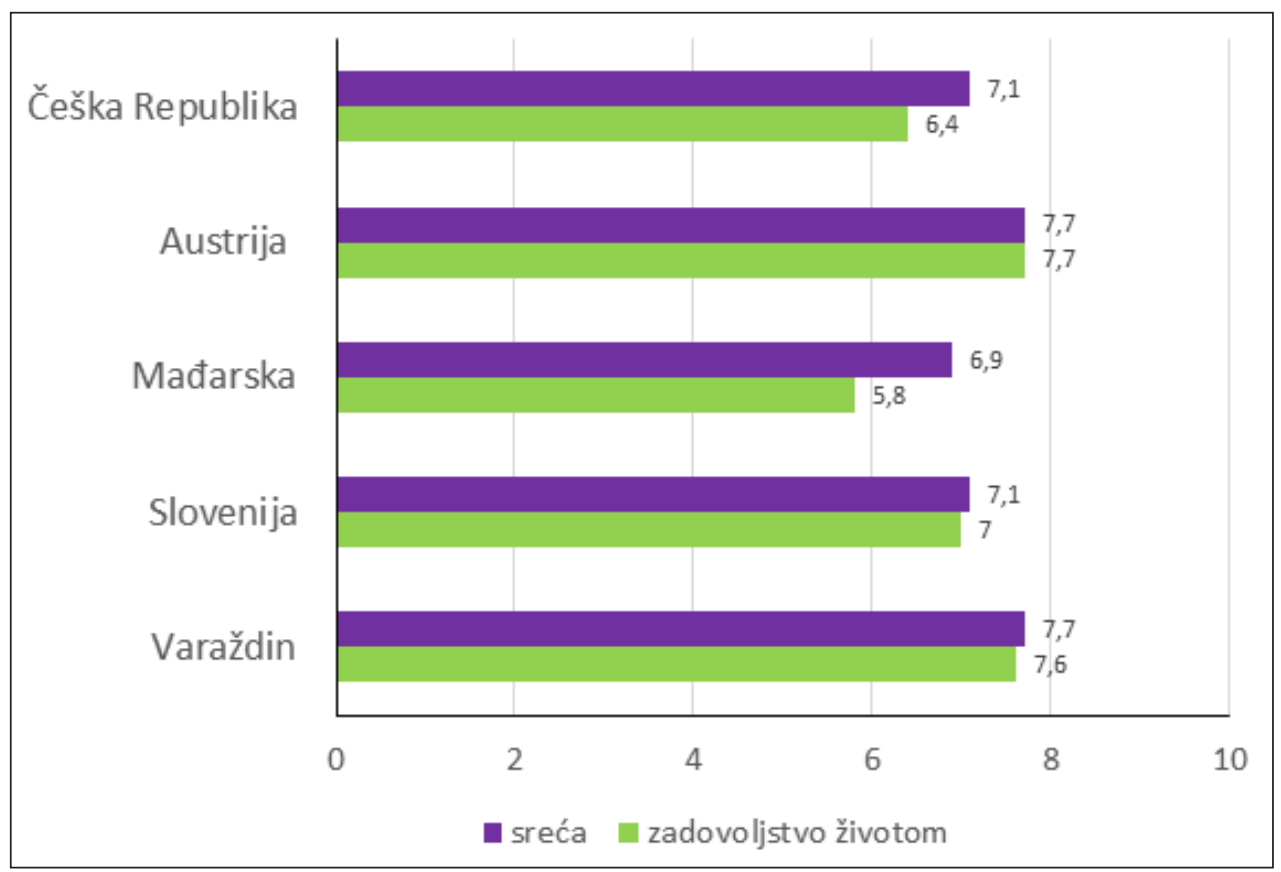

Slika 10. Usporedba procjena sreće i zadovoljstva životom stanovnika Varaždina, Slovenije, Mađarske, Austrije i Češke Republike

Za buduća istraživanja valja naglasiti važnost kontinuiranog praćenja kvalitete življenja građana Varaždina, a posebno u slučajevima u kojima se očekuju značajne promjene. Tako se možemo zapitati je li kvaliteta življenja građana Varaždina 2016. godine ista kao što je bila i pet godina ranije, 2011.; jesu li promjene koje su se u ovih 5 godina dogodile u različitim domenama u gradu imale neki utjecaj na procjenu kvalitete života građana grada Varaždina? To su samo neka od pitanja na koja možemo odgovoriti provedbom novih istraživanja o kvaliteti života u Varaždinu. Nadalje, bilo bi interesantno ispitati kvalitetu života građana Varaždina različite životne dobi, poglavito mladih i starih, različitog obrazovanja, socijalnog statusa, s nižim prihodima, nezaposlenih osoba, kao i usporediti te procjene s procjenama kvalitete života u drugim hrvatskim gradovima. Ono što za sada znamo o procjenama kvalitete života građana Varaždina u usporedbi s drugim gradovima, jest da je 2011. godine većina stanovnika smatrala kako je kvaliteta života u Varaždinu bolja u usporedbi s procjenama građana u drugim dijelovima Hrvatske.

Dobivene rezultate potrebno je uzeti s velikim ograničenjem, jer usporedbe podataka na različitim skalama i uzorcima i u određenom vremenu, posebno kada se ne radi o reprezentativnim uzorcima - što je slučaj u našem istraživanju 
s podacima Europskog istraživanja o kvaliteti života - uvijek treba promatrati sa velikom zadrškom.

\section{ZAKLJUČAK}

Općenito, stanovnici grada Varaždina procjenjuju da su sretni i zadovoljni svojim životom u cijelosti. Kod procjene zadovoljstva pojedinim segmentima svoga života odnosno uvjetima života u gradu Varaždinu građani su najzadovoljniji odnosima s bližnjima, pripadnošću okolini u kojoj žive, kvalitetom stanovanja, zatim duhovnošću, osjećajem vlastite sigurnosti i sigurnosti u gradu. Ujedno, to su područja koja građani procjenjuju pozitivnije nego što su procijenili zadovoljstvo svojim životom u cijelosti. Građani svoje pozitivne procjene zadovoljstva životom upravo baziraju na procjenama osobnog zadovoljstva, interpersonalnim odnosima i osjećaju sigurnosti kao socijalnim domenama života. što bi bili i glavni razlozi zbog kojih bi se stanovnici grada odselili iz Varaždina. Procjene životnog zadovoljstva, sreće i pojedinih domena životnog zadovoljstva građana Varaždina bliže su prosječnim procjenama stanovnika EU-a 2011. godine nego prosječnim procjenama stanovnika Hrvatske.

\section{LITERATURA}

1. C. BATZ, S. PARRIGON, L. TAY, (2015). The Impact of Scale Transformations on National Subjective Well-Being Scores. Social Indicators Research. Advance online publication. doi: 10.1007/s11205-015-1088-1.

2. A. BRAJŠA-ŽGANEC, M. MERKAŠ, I. ŠVERKO, (2011). Quality of life and leisure activities : How do leisure activities contribute to subjective well-being? Social indicators research, 102, 1; 81-91.

3. R. A. CUMMINS, (2012). The determinants of happiness. International Happiness and Development, 1, 1, 86-111.

4. R. A. CUMMINS, R. ECKERSLEY, J. PALLANT, J. VAN VUGT, \& R. MISAJON, (2003). Developing a national index of subjective wellbeing: The Australian Unity Wellbeing Index. Social Indicators Research, 64, 159-190.

5. T. DE JONGE, R. VEENHOVEN, L. ARENDS, (2014). Homogenizing Responses to Different Survey Questions on the Same Topic: Proposal of a Scale Homogenization Method Using a Reference Distribution. Social Indicators Research, 117; 275-300.

6. E. DIENER, (1984). Subjective well-being. Psychological Bulletin, 95(3), 542-575.

7. E. DIENER, (2000). Subjective well-being: The science of happiness, and a proposal for national index. American Psychologist, 55, 34-43. 
8. E. DIENER, (2006). Guidelines for national indicators of subjective well-being and ill-being. Journal of Happiness Studies, 7,4, 397-404.

9. E. DIENER, S. OISHI, \& R. E. LUCAS, (2003). Personality, culture, and subjective well-being: Emotional and cognitive evaluations of life. Annul Review of Psychology, 54, 403-425.

10. E. DIENER \& SELIGMAN MEP. (2002). Very happy people. Psychological Science.; 13:80-83.

11. E. DIENER \& E. SUH, (1997). Measuring quality of life: economic, social, and subjective indicators. Social Indicators Research, 40, 189-216.

12. E. DIENER, E. SUH, R. LUCAS \& SMITH H. (1999). Subjective well-being: Three decades of progress. Psychological Bulletin, 125, 276-302.

13. E. DIENER, L. TAY, S. OISHI (2013). Rising income and the subjective well-being of nations. Journal of Personality and Social Psychology 2013;104 (2):267-276.

14. DIENER, E., R. A. EMMONS, R. J. LARSEN, \& S. GRIFFIN, (1985). The satisfaction with life scale. Journal of Personality of Assessment, 49, 71-75.

15. DZS (2017). Statističke informacije. Državni zavod za statistiku Republike Hrvatske, Zagreb 2017, https://www.dzs.hr/.

16. R. A. EASTERLIN, (2012). Life satisfation of rich and poor under socialism and capitalisam. International Happiness and Development, 1, 1, 112-126.

17. EUROBAROMETER (2015). Standard Eurobarometer 83 / Spring 2015: Public Opinion in the European Union. Brussels: European Commission, DirectorateGeneral for Communication.

18. EUROFOUND. (2014). Trends in quality of life - Croatia: 2007-2012, Luxembourg: Publication Office of the European Union.

19. M. W. FORDYCE, (1988). A review of results on the happiness measures: A 60-second index of happiness and mental health. Social Indicators Research, 20, 355-381.

20. F. A. HUPPERT, (2009). Psychological Well-being: Evidence Regarding its Causes and Consequences. Applied Psychology: Health and Well-Being, 2009, 1 (2), 137-164.

21. LJ. KALITERNA LIPOVČAN, T. BABAROVIĆ, A. BRAJŠA-ŽGANEC, P. BEJAKOVIĆ, L. JAPEC, (2015). Trendovi u kvaliteti života Hrvatska:2007-2012. S posebnim naglaskom na životni standard i tržište rada. Radno pravo, 5, 64-70.

22. LJ. KALITERNA LIPOVČAN, A. BRAJŠA-ŽGANEC; S. BORIĆ, (2014). What is good for tourists should be good for residents too : the relationship between 
the quality of the touristic offer and subjective well-being of residents. Tourism Analysis, 19, 6; 719-730.

23. LJ. KALITERNA LIPOVČAN, T. BRKLJAČIĆ, V. ŠAKIĆ (2007). Monthly income and subjective well-being of croatian citizens. Croatian Medical Journal; 48: 727-733.

24. LJ. KALITERNA LIPOVČAN, J. BURUŠIĆ (2014). Age and Gender Differences in Well-being in Croatia. In Eckermann E. Ed. Gender, Lifespan and Quality of Life: An International Perspective. Dordrecht, NL: Springer. pp. 199-219.

25. C. KIM-PRIETO, E. DIENER, M. TAMIR, C. N. SCOLLON, \& M. DIENER, (2005). Integrating the diverse definitions of happiness: A time-sequential framework of subjective well-being. Journal of Happiness Studies: An Interdisciplinary Periodical on Subjective Well-Being, 6, 261-300.

26. I. KRISTOFFERSEN, (2017). The metrics of subjective wellbeing data: An empirical evaluation of the ordinal and cardinal comparability of life satisfaction scores. Social Indicators research, 130, 2, 845-865.

27. S. LYUBOMIRSKY, L. KING, E. DIENER (2005). The benefits of frequent positive affect: Does happiness lead to success? Psychological Bulletin, 131:803-855.

28. A. MIŠETIĆ,; R. KRNIĆ, G. KOZINA, (2013). Actors in the planning and development of Varaždin : the contribution of social sustainability research in the urban context. Društvena istraživanja, 22, 1; 143-165.

29. K. OTT, M. BRONIĆ, B. STANIĆ, (2016). Ostvarenje proračuna općina, gradova i županija u 2015.Newsletter povremeno glasilo instituta za javne financije, 108.; http://www.ijf.hr/upload/files/108.pdf

30. W. PAVOT, E. DIENER, (2004). The subjective evaluation of well-being in adulthood: Findings and implications. Aging International, 29(2), 113-135.

31. C. PROCTOR (2014). Encyclopedia of quality of life and well-being research. In: A. Michalos, Ed. Springer. pp 6437-6441.

32. L. STOLL, , J. MICHELSON, , C. SEAFORD, (2012). Well-being evidence for policy: A review. New Economics Foundation.

33. M. ŠICEL, S. KAŠTELA, (ur.) (2009). 800 godina slobodnog kraljevskog grada Varaždina 1209.-2009. Zagreb - Varaždin: Hrvatska akademija znanosti i umjetnosti - Zavod za znanstveni rad u Varaždinu.

34. R. VEENHOVEN, (2010). Greater happiness for a greater number - is that possible and desirable?. Journal of happiness studies, 11, 5, 605-629. 


\section{SAŽETAK}

\section{KVALITETA ŽIVLJENJA GRAĐANA GRADA VARAŽDINA: USPOREDBA S EUROPSKOM UNIJOM}

Postoji niz čimbenika koji pridonose kvaliteti života pojedinca. Cilj istraživanja bio je ispitati kvalitetu življenja građana grada Varaždina odnosno procjenu općeg životnog zadovoljstva kao i pojedinih domena životnog zadovoljstva te sreće građana grada Varaždina i zatim napraviti usporedbu s procjenama kvalitete života građana Hrvatske, susjednih zemalja i općenito građana Europske unije. Istraživanje je provedeno u jesen 2011. na reprezentativnom, stratificiranom uzorku punoljetnog stanovništva Grada Varaždina, sa slučajnim izborom jedinica unutar svakog stratuma. Uzorkom je ukupno obuhvaćeno 500 ispitanika. Korištene su subjektivne procjene kvalitete življenja građana Varaždina ispitane skalama samoprocjena o kvaliteti života, životnom zadovoljstvu i sreći, te pojedinim domenama životnog zadovoljstva. Rezultati provedenog istraživanja pokazali su kako stanovnici grada Varaždina općenito procjenjuju da su sretni i zadovoljni svojim životom u cijelosti. Kod procjene zadovoljstva pojedinim segmentima u svom životu, odnosno uvjetima života u gradu Varaždinu, građani su najzadovoljniji odnosima s bližnjima, pripadnošću okolini u kojoj žive, kvalitetom stanovanja, zatim duhovnošću, osjećajem vlastite sigurnosti i sigurnosti u gradu. Ujedno, to su područja koja građani procjenjuju pozitivnije nego što su procijenili zadovoljstvo svojim životom u cijelosti. Građani svoje pozitivne procjene zadovoljstva životom upravo baziraju na procjenama osobnog zadovoljstva, interpersonalnim odnosima i osjećaju sigurnosti kao socijalnim domenama život, a što bi bili i glavni razlozi zbog kojih bi se stanovnici grada odselili iz Varaždina. Za zadovoljstvo životom građana grada Varaždina najznačajniji su zadovoljstvo životnim standardom i zadovoljstvo pripadnosti okolini u kojoj žive. Procjene životnog zadovoljstva, sreće te pojedinih domena životnog zadovoljstva građana Varaždina bliže su prosječnim procjenama stanovnika EU-a 2011. godine nego prosječnim procjenama stanovnika Hrvatske. Zadovoljstvo svojim zdravljem građani Varaždina, Hrvatske i EU-a procjenjuju podjednako, dok su procjene životnog standarda građana Varaždina bliže procjenama stanovnika EU-a nego stanovnika Hrvatske. Procjene životnog zadovoljstva i sreće građana Varaždina u odnosu na ostale zemlje EU-a u okruženju najbliže su procjenama stanovnika Austrije.

Ključne riječi: kvaliteta života; čimbenici kvalitete života; građani Varaždina; građani EU. 


\section{SUMMARY}

\section{THE QUALITY OF LIFE OF CITIZENS IN THE CITY OF VARAŽDIN: A COMPARISON WITH THE EUROPEAN UNION}

There are a number of factors that contribute to the quality of life of an individual. The aim of this study was to examine the quality of life of citizens in the city of Varaždin and to assess their general life satisfaction as well as individual domains of life satisfaction and happiness. Another aim was to compare this with the evaluated quality of life of citizens in Croatia, neighbouring countries and generally in the European Union. The survey was conducted in the fall of 2011 on a representative, stratified sample of the adult population in the city of Varaždin with a random selection of units within each stratum. The sample included a total of 500 respondents. Subjective assessments of quality of life by citizens of Varaždin were tested by scales of self-assessment of quality of life, life satisfaction and happiness, and individual domains of life satisfaction. Results of the study showed that people in the city of Varaždin evaluate that they are happy and satisfied with their life in general. When assessing satisfaction of certain life segments and living conditions in the city of Varaždin, citizens are most satisfied with their family relationships, belonging to the environment in which they live, the quality of housing, followed by spirituality, a sense of personal safety and security in the city. At the same time, these are the areas that citizens assessed more positively than they assess satisfaction with their lives as a whole. Citizens' positive assessment of life satisfaction is based on evaluations of personal satisfaction, interpersonal relationships and a sense of security as well as the social domains of life which would be the main reasons why residents move away from Varaždin. For life satisfaction of citizens in the city of Varaždin, standard of living and the pleasure of belonging to the environment in which they live were the most important. Life satisfaction, happiness and individual domains of life satisfaction of citizens of Varaždin were closer to the average evaluations in the EU in 2011, than the average evaluations of the Croatian population. In relation to satisfaction with health, citizens of Varazdin, Croatia and the EU are alike, while the standard of living assessment among citizens of Varaždin is closer to the evaluations of the EU population than the overall population of Croatia. Evaluations of life satisfaction and happiness of citizens in Varaždin were closest to evaluations of population in Austria in comparison to other EU countries in the region.

Key Words: quality of life; factors of quality of life; citizens of Varaždin; citizens of the EU. 